\title{
Chimeric Antigen Receptor-Modified T Cells and T Cell-Engaging Bispecific Antibodies: Different Tools for the Same Job
}

\author{
Melanie Schwerdtfeger ${ }^{1,2}$ - Mohamed-Reda Benmebarek ${ }^{1}$ - Stefan Endres ${ }^{1,3,4} \cdot$ Marion Subklewe $^{5}$. \\ Vincenzo Desiderio ${ }^{2} \cdot$ Sebastian Kobold ${ }^{1,3,4}$
}

Accepted: 25 March 2021 / Published online: 30 April 2021

(C) The Author(s) 2021

\begin{abstract}
Purpose of Review Both chimeric antigen receptor (CAR) T cells and T cell-engaging antibodies (BiAb) have been approved for the treatment of hematological malignancies. However, despite targeting the same antigen, they represent very different classes of therapeutics, each with its distinct advantages and drawbacks. In this review, we compare BiAb and CAR T cells with regard to their mechanism of action, manufacturing, and clinical application. In addition, we present novel strategies to overcome limitations of either approach and to combine the best of both worlds.

Recent Findings By now there are multiple approaches combining the advantages of BiAb and CAR T cells. A major area of research is the application of both formats for solid tumor entities. This includes improving the infiltration of $\mathrm{T}$ cells into the tumor, counteracting immunosuppression in the tumor microenvironment, targeting antigen heterogeneity, and limiting offtumor on-target effects.

Summary BiAb come with the major advantage of being an off-the-shelf product and are more controllable because of their halflife. They have also been reported to induce less frequent and less severe adverse events. CAR T cells in turn demonstrate superior response rates, have the potential for long-term persistence, and can be additionally genetically modified to overcome some of their limitations, e.g., to make them more controllable.
\end{abstract}

Keywords Chimeric antigen receptor $\cdot$ Bispecific antibody $\cdot$ Immunotherapy $\cdot$ Adoptive T cell therapy $\cdot \mathrm{T}$ cell redirection $\cdot$ Cancer

This article is part of the Topical Collection on CART and immunotherapy

Center of Integrated Protein Science Munich (CIPS-M) and Division of Clinical Pharmacology, Department of Medicine IV, Klinikum der Universität München, LMU Munich, Munich, Germany, is a member of the German Center for Lung Research (DZL).

Sebastian Kobold

sebastian.kobold@med.uni-muenchen.de

Melanie Schwerdtfeger

melanie.schwerdtfeger@med.uni-muenchen.de

Mohamed-Reda Benmebarek

mohamedreda.benmebarek@med.uni-muenchen.de

Stefan Endres

endres@1mu.de

Marion Subklewe

marion.subklewe@med.uni-muenchen.de

Vincenzo Desiderio

vincenzo.desiderio@unicampania.it
1 Center of Integrated Protein Science Munich (CIPS-M) and Division of Clinical Pharmacology, Department of Medicine IV, Klinikum der Universität München, LMU Munich, Munich, Germany

2 Department of Experimental Medicine, University of Campania "Luigi Vanvitelli", Naples, Italy

3 German Center for Translational Cancer Research (DKTK), Munich, Germany

4 Einheit für Klinische Pharmakologie (EKLiP), Helmholtz Zentrum München, German Research Center for Environmental Health (HMGU), Neuherberg, Germany

5 Department of Medicine III, Klinikum der Universität München, LMU Munich, Munich, Germany 


\section{Introduction}

In efforts to harness $\mathrm{T}$ cells in the fight against cancer, several immunotherapeutic approaches have been successfully developed. Among others, chimeric antigen receptor (CAR) T cells and $\mathrm{T}$ cell-engaging bispecific antibodies $(\mathrm{BiAb})$ have gained approval by regulatory agencies and are currently being used to treat patients with hematological malignancies.

Both BiAb and CAR T cells use antibodies or antibody fragments to redirect $\mathrm{T}$ cells to specific tumor-associated antigens, which is a shared facet of these major histocompatibility complex (MHC)-independent approaches. Their clinical application has achieved unprecedented response rates in patients with relapsed or refractory B cell malignancies, although in only partially overlapping indications $[1,2]$. Both can induce severe adverse events like cytokine release syndrome (CRS) and neurotoxicity. Further, a large proportion of patients inevitably relapse, and the efficacy of BiAb or CAR T cells targeting solid tumors remains limited $[3 \bullet \bullet$.

$\mathrm{BiAb}$ are recombinant proteins with antigen-binding antibody domains both for $\mathrm{T}$ cell-specific and tumor-associated antigens. When infused into the patient, they can redirect endogenous $\mathrm{T}$ cells to kill cancer cells expressing a specific target [4].

CAR T cells are usually generated by genetically modifying patient-derived $\mathrm{T}$ cells ex vivo before their adoptive transfer back into the patient. A CAR is a synthetic receptor consisting of a single-chain variable fragment ( $\mathrm{scFv}$ ) linked to a transmembrane domain and intracellular T cell-activating domains. CAR binding to the antigen on the tumor cell surface activates the CAR $T$ cell and triggers a $\mathrm{T}$ cell response against antigen-expressing tumor cells [5•].

In this review, we present and describe different formats of $\mathrm{BiAb}$ and CAR $\mathrm{T}$ cell therapies. We compare BiAb with CAR $T$ cells, highlighting the differences and similarities, as well as the advantages and limitations of either strategy. In line with this, we outline preclinical and clinical strategies that are currently in development to overcome therapeutic limitations and boost efficacy.

\section{T Cell-Engaging Bispecific Antibodies}

The term BiAb will be used in this review for all antibodybased molecules containing antigen-binding sites for both $\mathrm{T}$ cell and tumor-associated antigens. Generally, BiAb can be divided into $\mathrm{BiAb}$ containing an $\mathrm{Fc}$ domain and $\mathrm{Ab}$ fragmentbased ones. Labrijn et al. provide an extensive overview of the different $\mathrm{BiAb}$ formats [6•].

Most $\mathrm{BiAb}$ with an $\mathrm{Fc}$ domain bear mutations introduced to abolish Fc-mediated effector functions such as antibodydependent cellular cytotoxicity, phagocytosis, and complement-dependent cytotoxicity, given that they can result in off-target immune cell activation $[6 \bullet, 7,8]$. However, these
$\mathrm{BiAb}$ are usually designed to maintain binding of the neonatal Fc receptor (FcRn) which protects them from degradation, thus conferring a long plasma half-life (days) compared to the plasma half-life of fragment-based BiAb (hours) [9-13]. This can be advantageous as they can be administered in a bolus injection, whereas fragment-based BiAb need to be infused continuously. The drawback is that they are more slowly eliminated from the circulation in the occurrence of adverse events. Fragment-based BiAb can be produced relatively easily at high yields and low costs but are more prone to aggregation or stability issues [14]. Generally, they exhibit faster tissue penetration than $\mathrm{Fc}$-containing $\mathrm{BiAb}$, including crossing of the blood-brain barrier. This distinction is a doubleedged sword, as it may increase patient susceptibility to neurotoxicity, while being more favorable for the treatment of brain tumors [15•]. The opposite applies to larger BiAb with an Fc domain, which are actively exported from the brain by transcytosis mediated by FcRn [9].

$\mathrm{BiAb}$ valency, i.e., the number of binding arms, as well as the affinity of the individual binding domains can greatly influence the functionality and biodistribution of a $\mathrm{BiAb}$. In the case of a $\mathrm{CD} 3$-binding $\mathrm{BiAb}$, one binding site for $\mathrm{CD} 3$ is preferred to prevent unwanted $\mathrm{T}$ cell activation by $\mathrm{CD} 3$ cross-linking [2••]. A reduced affinity for $\mathrm{CD} 3$ can minimize BiAb trapping in tissues containing a high number of $\mathrm{T}$ cells $[6 \bullet, 16,17]$. In addition, BiAb with reduced potency can be administered at higher doses to augment efficacy while limiting adverse events. In contrast, two tumor antigen-binding domains can increase selective recognition and killing of highly antigen-expressing tumor cells by increasing the avidity (through the simultaneous binding of both arms) while sparing healthy cells expressing the antigen at lower levels [7, 18-20]. In addition, lowering the affinity for both the $\mathrm{CD} 3$ and tumor antigen-binding domains have also been shown to widen the therapeutic window [21].

In 2009, the first BiAb was approved by the European Medicines Agency (EMA). Although more than $40 \mathrm{BiAb}$ are currently in phase 1 and 2 clinical trials for both hematological and solid cancers, to date only two molecules have gained regulatory approval for cancer therapy [22]. Removab® (catumaxomab), an anti-CD3 $\times$ anti-epithelial cellular adhesion molecule (EpCAM) BiAb containing an $\mathrm{Fc}$ domain, was intraperitoneally applied to treat malignant ascites in ovarian cancer but was withdrawn from the market in 2017 for commercial reasons.

Blincyto ${ }^{\circledR}$ (blinatumomab), an anti-CD3 $\times$ anti-CD19 fragment-based bispecific $\mathrm{T}$ cell engager (BiTE®), is the only $\mathrm{BiAb}$ currently on the market. It gained approval for B cell precursor acute lymphoblastic leukemia (ALL) by the US Food and Drug Administration (FDA) in 2014 and by the European Medicines Agency in 2015. Lacking an Fc domain, and thus not protected from degradation by FcRn, it has a halflife of approximately 1 to $2 \mathrm{~h}$ and can therefore only be administered via a continuous intravenous infusion $[10,11]$. 
Complete response rates ranged from 36 to $69 \%$ in clinical trials (see Table 1).

Other BiAb currently under clinical investigation include, e.g., BiTE molecules targeting CD20 in chronic lymphoblastic leukemia, CD33 in acute myeloid leukemia, and B cell maturation antigen (BCMA) in multiple myeloma [15•].

Beyond BiAb, CAR T cells comprise a promising arm of cancer immunotherapy which is introduced in the next section.

\section{CAR T Cells}

CAR structure typically consists of an extracellular antigen recognition domain (in most cases an antibody-derived $\mathrm{scFv}$ ) connected via a spacer and a transmembrane domain to one or more intracellular signaling domains [23•]. These domains determine the type of signal transmitted after the $\mathrm{scFv}$ engages its target. While first generation CAR constructs can only propagate signal 1 via the intracellular $\mathrm{CD} 3 \zeta$ chain of

Table 1 Comparison between CAR T cells and BiAb

\begin{tabular}{|c|c|c|}
\hline & CAR T cells & $\mathrm{BiAb}$ \\
\hline Structure & $\begin{array}{l}\mathrm{T} \text { cells genetically engineered to express a synthetic } \\
\text { receptor consisting of an extracellular scFv linked } \\
\text { to intracellular activation and co-stimulatory } \\
\text { domains }\end{array}$ & $\begin{array}{l}\text { Recombinant soluble protein with binding domains } \\
\text { for a T cell and a tumor antigen }\end{array}$ \\
\hline Signals for $\mathrm{T}$ cell activation & $\begin{array}{l}\text { Signal } 1(\mathrm{CD} 3 \zeta) \text {, signal } 2 \text { (CD28, 4-1BB; in 2nd and } \\
\text { 3rd generation CAR constructs), signal } 3 \\
\text { (cytokine stimulation ex vivo) }\end{array}$ & Signal $1(\mathrm{CD} 3 \zeta)$ \\
\hline Immune synapse & Atypical $[37]$ & Classical [36] \\
\hline Effector cells & $\begin{array}{l}\text { Engineered } \mathrm{CD}^{+} \text {and } \mathrm{CD} 4^{+} \mathrm{T} \text { cells; less } \\
\text { differentiated } \mathrm{T} \text { cells show better efficacy in vivo }\end{array}$ & $\begin{array}{l}\text { Endogenous } \mathrm{CD}^{+} \text {and } \mathrm{CD} 4^{+} \mathrm{T} \text { cells; mainly } \\
\text { antigen-experienced } \mathrm{T} \text { cells kill }\end{array}$ \\
\hline Manufacturing & $\begin{array}{l}\text { Autologous CAR T cells: individual production for } \\
\text { each patient } \\
\text { Allogeneic CAR T cells: production in batches from } \\
\text { healthy donor T cells (investigational use only) } \\
\text { Prone to manufacturing variability ( } \mathrm{T} \text { cell subset } \\
\text { composition, transduction efficiency, number of } \\
\text { viable T cells) and failure }\end{array}$ & Off-the-shelf product \\
\hline Pre-treatment & $\begin{array}{l}\text { Lymphocyte apheresis for collecting T cells (for } \\
\text { autologous T cells), lymphodepletion } \\
\text { chemotherapy before CAR T cell infusion }\end{array}$ & Dexamethasone to limit CRS and neurotoxicity \\
\hline Dosing & Single dose & $\begin{array}{l}\text { Multiple dosing, for short half-life formats } \\
\text { continuous infusion }\end{array}$ \\
\hline Costs & Up to $320,000 €$ in Germany [63] & Up to $293,000 €$ in Germany [64] \\
\hline Regulatory approval & $\begin{array}{l}\text { Kymriah: r/r B cell precursor ALL patients up to } 25 \\
\text { years (FDA 2017, EMA 2018), adult patients with } \\
\text { large B cell lymphoma (FDA and EMA 2018) [25, } \\
\text { 27] } \\
\text { Yescarta: adult patients with large B cell lymphoma } \\
\text { (FDA 2017, EMA 2018) [26, 28] } \\
\text { Tecartus: adult patients with r/r mantle cell } \\
\text { lymphoma (FDA and EMA 2020) }[29,30]\end{array}$ & $\begin{array}{l}\text { Blinatumomab: r/r B cell precursor ALL (FDA 2014, } \\
\text { EMA } 2015 \text { (only Philadelphia } \\
\text { chromosome-negative ALL)), B cell precursor } \\
\text { ALL with minimal residual disease (FDA 2018, } \\
\text { EMA } 2019 \text { (only adults)) [65, 66] }\end{array}$ \\
\hline Complete response rates $(\mathrm{CR} / \mathrm{CRh} / \mathrm{CRi})$ & $\begin{array}{l}\text { Adult B cell ALL: } 83 \text { to } 93 \% \text { [67-69] } \\
\text { Pediatric B cell ALL: } 70 \text { to } 94 \% \text { [70-73] } \\
\text { Diffuse large B cell lymphoma: } 40 \text { to } 57 \% \text { [52, 53, } \\
\quad 74,75] \\
\text { Mantle cell lymphoma: } 67 \%[31]\end{array}$ & Adult B cell ALL: 36 to $69 \%$ [76-80] \\
\hline Relapse rates (\% of complete responders) & $\begin{array}{l}\text { Adult B cell ALL: } 12 \text { to } 61 \%[68,69] \\
\text { Pediatric B cell ALL: } 26 \text { to } 40 \%[70-72] \\
\text { Diffuse large B cell lymphoma: } 21 \%[75]\end{array}$ & Adult B cell ALL: 40 to $70 \%[76-78,80]$ \\
\hline CD19-negative relapse (\% of all relapses) & B cell ALL: 16 to $68 \%$ [69-72] & Adult B cell ALL: 8 to $30 \%[76,81]$ \\
\hline Toxicities & $\begin{array}{l}\text { More frequent and severe CRS ( } \geq \text { grade } 3: 13 \text { to } \\
47 \% \text { ) and neurotoxicity }(\geq \text { grade } 3: 5 \text { to } 50 \% \text {, } \\
\text { on-tumor off-target effects (B cell aplasia when } \\
\text { targeting CD19) }[52,53,68-71,73,75]\end{array}$ & $\begin{array}{l}\text { CRS ( } \geq \text { grade } 3: 2 \text { to } 6 \% \text { ) and neurotoxicity ( } \geq \text { grade } \\
\text { 3: } 7 \text { to } 17 \% \text { ), on-tumor off-target effects (B cell } \\
\text { aplasia when targeting CD19) }[76-80]\end{array}$ \\
\hline
\end{tabular}


the TCR complex, second-generation CAR constructs have an additional co-stimulatory domain, in most cases the intracellular domain of CD28 or 4-1BB, through which signal 2 is transmitted. In third-generation CAR constructs, two costimulatory domains are included, further augmenting the co-stimulus.

Individual CAR features can greatly impact CAR T cell function, including $\mathrm{T}$ cell phenotype, persistence, tonic signaling, and on-target off-tumor effects. For example, lowering the affinity of the scFv can help CAR T cells discern tumor cells differentially expressing the antigen from healthy cells expressing it at lower levels, thus limiting on-target off-tumor responses [24]. In addition, exchanging the co-stimulatory domain has been shown to impact $\mathrm{T}$ cell activation as well as the in vivo persistence of CAR T cells (as observed when swapping the CD28 co-stimulus for 4-1BB) [23•]. Also, the transduction of specific $\mathrm{T}$ cell subsets, the method of transgene delivery, and selection of the promoter can influence the efficacy and adverse effects of CAR T cells [1, 23•]. This topic has recently been reviewed in more detail elsewhere [23 ${ }^{\bullet}$.

After clinical trials showed dramatic response rates, two CAR $T$ cell products targeting the B cell antigen CD19 received marketing authorization by the FDA in 2017 and the EMA in 2018 for relapsed or refractory ( $r / r)$ B cell malignancies after two or more lines of systemic treatment [25-28]. Kymriah (tisagenlecleucel) is approved for $\mathrm{r} / \mathrm{r} \mathrm{B}$ cell precursor ALL and large B cell lymphoma, and Yescarta (axicabtagene ciloleucel) for large B cell lymphoma. Both use secondgeneration CAR constructs but differ in their co-stimulatory domains: 4-1BB for Kymriah and CD28 for Yescarta. Complete response rates in ALL range from 70 to $94 \%$ but are lower in diffuse large B cell lymphoma with 40 to $57 \%$ (see Table 1).

In addition, Tecartus (brexucabtagene autoleucel) has been approved in 2020 by the FDA and EMA for $r / r$ mantle cell lymphoma [29, 30]. It utilizes the same antiCD19 CAR as Yescarta and achieved a complete response in $67 \%$ of patients in the clinical trial that led to its regulatory approval [31].

More than 200 CAR T cell products are currently being evaluated in clinical trials for a variety of different targets in both hematological and solid malignancies, with more than 40 trials started in 2020 alone [32, 33]. For example, anti-BCMA CAR T cells have shown promising results in multiple myeloma patients and are currently under regulatory review [34]. Most studies use patient-derived autologous $\mathrm{T}$ cells, while a minority uses allogeneic $\mathrm{T}$ cells from healthy donors. Allogeneic $\mathrm{T}$ cells on the one hand hold the promise of a standardized off-the-shelf product with lower costs and the added option for repeated infusions. On the other hand, they need to include additional genetic modifications to lower the risk of graft-versus-host disease and alloimmunization $[3 \bullet \bullet]$.
There is certainly more to come from CAR T cells as anticancer therapeutics. This growing potential, and how it compares to that of $\mathrm{BiAb}$ therapy, are outlined below.

\section{Comparison of CAR T Cells and BiAb}

Both CAR and BiAb approaches are distinctly advantageous in their own right. Although a clinical trial comparing these approaches within the same cohort for the same indication is still lacking, it remains important to compare and contrast these approaches. This is what we aim to outline in this section, highlighting differences in their mode of action, manufacturing, and clinical applications.

\section{Signals Provided for T Cell Activation}

Optimal $\mathrm{T}$ cell activation requires three signals: signal 1 is normally provided by the T cell receptor (TCR)-major histocompatibility complex (MHC) interaction, signal 2 through a co-stimulatory receptor on the $\mathrm{T}$ cells binding its ligand on antigen-presenting cells or target cells, and signal 3 by cytokines such as interleukin (IL)-2, IL-7, and IL-15 [3••, 35]. CAR activation itself provides signal 1 through the CD3 $\zeta$ intracellular domain and signal 2 through the co-stimulatory domains. BiAb only provide signal 1 by activating the CD3 receptor [3••, 35]. As CAR T cells are stimulated with cytokines during manufacturing, thereby providing signal 3, they have an additional advantage regarding $\mathrm{T}$ cell activation [35]. This may contribute to the fact that, based on the currently approved products, CAR T cells are considered more efficacious than blinatumomab (see Table 1).

\section{Immune Synapses and Killing Mechanisms}

BiAb-induced immune synapses formed between $\mathrm{T}$ cells and antigen-expressing target cells are very similar to the classical cytolytic immune synapse formed via the TCR-MHC interaction (Fig. 1a, b) [36]. In contrast, CAR T cells form an atypical synapse which is smaller and less organized and induces faster, stronger, and shorter signaling compared to the classical immune synapse (Fig. 1c). It also mediates faster target cell lysis by accelerated recruitment of lytic granules to the synapse and more rapid T cell detachment [37].

CAR T cells can kill antigen-expressing tumor cells via the release of cytotoxic granules containing perforin and granzymes, through the Fas-FasL pathway, and by sensitizing the tumor stroma following the release of pro-inflammatory cytokines [5•]. CAR activation was shown to upregulate FasL on T cells [38], and interferon- $\gamma$ stimulation leads to Fas upregulation on some colon carcinoma cell lines and increased their susceptibility to CAR T cell-mediated killing [39]. BiAb are known to induce cytotoxicity via perforin and granzyme B 
a

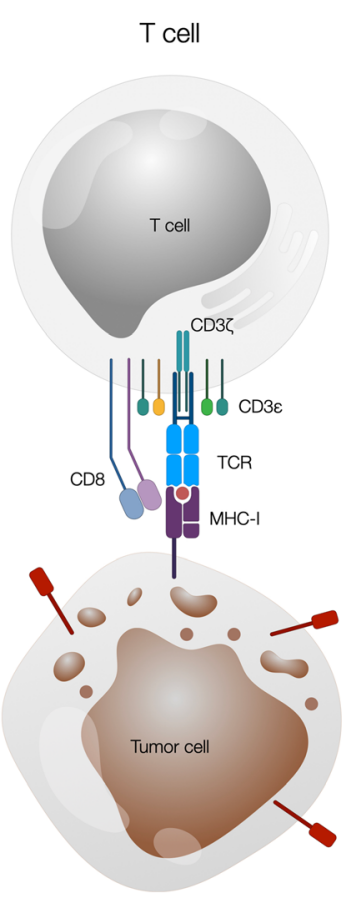

b

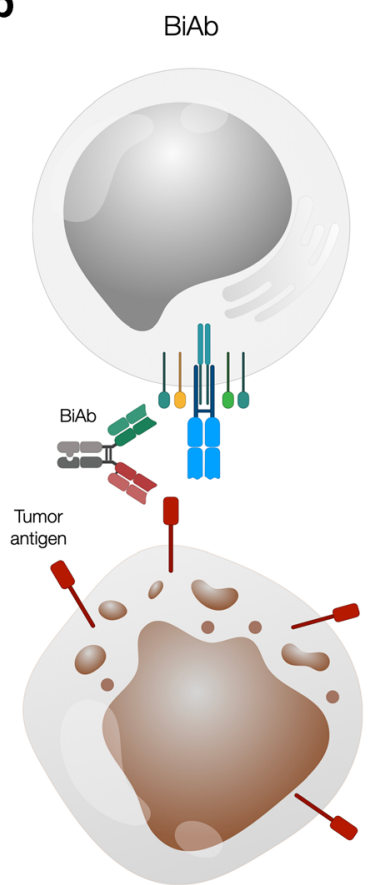

Fig. 1 Schematic presentation of the interaction between $\mathrm{T}$ cells and tumor cells via a TCR, a BiAb, a CAR, and a SAR in combination with a BiAb. a $\mathrm{A} \mathrm{CD} 8^{+} \mathrm{T}$ cell recognizes a tumor cell presenting a peptide from a tumor antigen on MHC class I via its TCR. b A BiAb mediates T cell recognition of a tumor cell by binding to both an antigen on the $T$ cell surface, most commonly CD3, and a tumor cell surface antigen. $\mathbf{c} \mathrm{A} T$ cell genetically modified to express a CAR binds a surface antigen expressed

[40]. Both BiAb and CAR T cells can mediate serial tumor cell killing [3••]. Interestingly, both strategies could mediate lysis of antigen-negative tumor cells that were in direct contact with antigen-positive cells, most likely involving the Fas-FasL axis in both cases [41, 42]. This suggests that Fas-FasL-based killing can also be mediated by BiAb.

\section{Antigen Spreading}

Following antigen-specific tumor cell lysis, the released antigens may be taken up by dendritic cells and cross-presented to $\mathrm{T}$ cells, priming additional $\mathrm{T}$ cell responses in a process known as antigen or epitope spreading. There is evidence demonstrating that tumor-specific $\mathrm{CD} 8^{+} \mathrm{T}$ cells can mediate this process [43]. After treatment with mesothelin-specific CAR T cells, novel antibodies in two cancer patients could be detected using high-throughput serological analysis and immunoblotting. Both patients showed clinical antitumor activity following treatment despite not receiving lymphodepletion therapy before CAR T cell infusion [44]. Another study could show that clonal expansion of endogenous $\mathrm{T}$ cells could be induced by anti-mesothelin CAR T cells in several solid tumor patients, which was detected by deep sequencing of the TCR beta chain. This was not observed in patients receiving lymphodepletion prior to CAR $\mathrm{T}$ cell

C

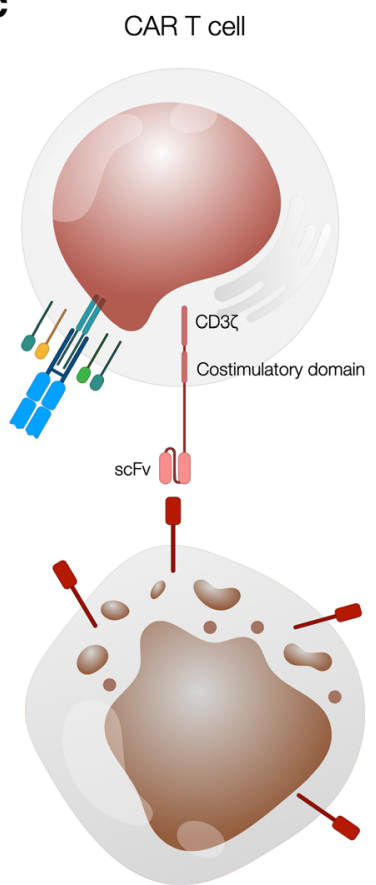

d

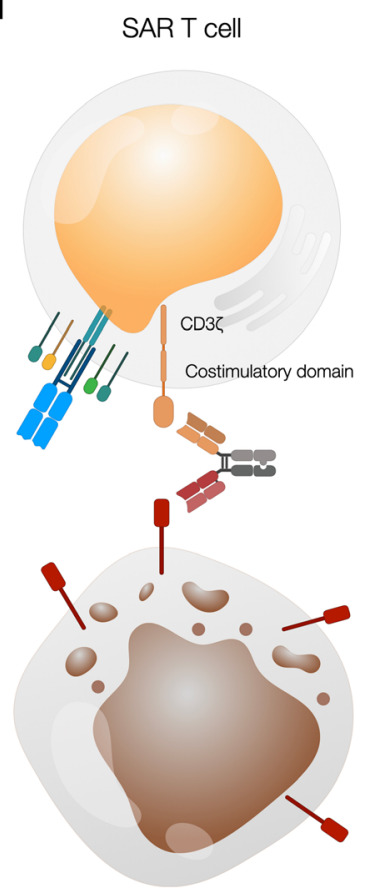

on the tumor cell via the scFv domain of the CAR in an MHCindependent manner. d A SAR-transduced T cell interacts with a tumor cell via a BiAb binding the SAR extracellular domain and a tumor cell surface antigen. BiAb, T cell redirecting bispecific antibody; CAR, chimeric antigen receptor; SAR, synthetic agonistic receptor; TCR, T cell receptor

transfer [45]. Taken together, these studies show that CAR T cells can induce broadening of humoral responses as well as T cell epitope spreading in patients, effects that appear to be hampered by lymphodepletion. An example of epitope spreading has also been reported for BiAb therapy. A BiTE targeting Wilms' tumor protein (WT1) led to the expansion of secondary $\mathrm{T}$ cell clones (with specificity for tumor-associated antigens other than WT1) in in vitro co-cultures of patient PBMCs with autologous tumor cells [46].

\section{$\mathrm{CD4}^{+} / \mathrm{CD8}^{+} \mathrm{T}$ Cells and T Cell Phenotype}

For both CAR $\mathrm{T}$ cells and $\mathrm{BiAb}, \mathrm{CD}^{+} \mathrm{T}$ cells not only provide support for $\mathrm{CD} 8^{+} \mathrm{T}$ cells but have been shown to be directly cytotoxic [47•], although in a slower fashion. Further, $\mathrm{CD}^{+} \mathrm{CAR} \mathrm{T}$ cells are less prone to activation-induced cell death $\left[1^{\bullet}\right]$ and persist longer in vivo [48].

While less differentiated CAR T cells (naïve, stem cell memory, central memory) show better efficacy in vivo, it is mainly antigen-experienced $\mathrm{T}$ cells (effector memory) that mediate lysis via $\mathrm{BiAb}[2 \bullet \bullet, 47 \bullet, 49 \bullet]$. Interestingly, $\mathrm{BiAb}$ have even been shown to redirect regulatory $\mathrm{T}$ cells to kill tumor cells [50]. 


\section{Manufacturing}

One of the greatest differences between the two strategies is the manufacturing process. Thus far, CAR T cells have to be produced individually for each patient, a costly and laborious process ( 2 to 4 weeks) spanning lymphocyte apheresis to reinfusion, during which the disease may progress [49॰]. After leukapheresis, patient $\mathrm{T}$ cells are isolated and activated before they are genetically modified with the CAR construct and expanded [51]. After quality testing, the product is shipped to the patient, who is pre-conditioned with lymphodepleting chemotherapy before CAR T cell infusion.

Lymphodepletion is not required prior to $\mathrm{BiAb}$ treatment. Additional obstacles for CAR T cell therapy include the challenge of achieving sufficient $\mathrm{T}$ cell numbers following leukapheresis and ex vivo expansion of the transduced $\mathrm{T}$ cells $[52,53]$.

In contrast, $\mathrm{BiAb}$ are off-the-shelf biologics that are easier to produce recombinantly and purify.

They bear the additional advantage of facile dose management, which is often challenging or not possible in the CAR T cell setting. However, based on the currently approved products, CAR $\mathrm{T}$ cells seem to be more efficacious than blinatumomab (see Table 1).

\section{T Cell Expansion and Persistence}

Another major difference between CAR T cells and BiAb is the reliance on $\mathrm{T}$ cell expansion and persistence. While CAR $\mathrm{T}$ cells greatly rely on CAR $\mathrm{T}$ cell expansion, which can be higher than 1000-fold [54], T cell expansion is less important for BiAb because any antigen-experienced $\mathrm{T}$ cell can be engaged for tumor cell killing [47•]. With respect to recurrence after successful therapy, CAR $\mathrm{T}$ cells possess the advantage that they can engraft long term in the patient and thus attack recurring tumors, while $\mathrm{BiAb}$ action is abolished shortly after the last infusion [47•]. The impact of gene editing approaches on the production of a more refined CAR T cell product will broaden this disparity in years to come [55].

\section{Adverse Events}

There are two main adverse events, one being CRS, a systemic response caused by antigen-specific $\mathrm{T}$ cell activation and subsequent release of pro-inflammatory cytokines. The other is neurotoxicity, otherwise referred to as immune effector cellassociated neurotoxicity syndrome (ICANS) [56]. CRS is generally more frequent and severe in CAR T cell therapy (see Table 1), often occurring in the first days after treatment and correlating with disease burden $[3 \cdot \bullet, 57,58]$. CRS and ICANS are currently managed using an IL-6 receptorblocking antibody (tocilizumab) and corticosteroids. To reduce these adverse events, pre-treatment with dexamethasone and step-up dosing have proven successful for blinatumomab, while split dosing has been tested in the CAR T cell setting [3••]. In addition, on-target off-tumor toxicities can be a major concern that depends on the expression profile of the targeted antigen in healthy tissues. In the case of B cell malignancies treated with anti-CD19 BiAb or CAR T cells, the consequent $\mathrm{B}$ cell aplasia has been largely manageable by the infusion of immunoglobulins $[59,60]$.

\section{Relapse}

Despite high initial response rates, many patients relapse after anti-CD19 CAR T cell or blinatumomab treatment (see Table 1). However, the rate of CD19-negative relapses after initially successful therapy seems to be higher in CAR T celltreated patients than in blinatumomab-treated patients (see Table 1). It is important to remember that blinatumomab is often used as a bridge to allogeneic stem cell transplantation. Such a transplantation would rather be the choice (if available) in case of relapse in spite of CAR T cell treatment [61, 62]. Along these lines, differences in antigen-loss variants might simply be a reflection of a lower treatment pressure with blinatumomab compared to CAR T cells $[2 \cdot \bullet]$. Many approaches that are currently in development aim to improve either therapy alone or combine the best of both approaches in efforts to develop novel solutions. These perspectives and their potential are discussed in the final section below.

$C R$ complete remission, $C R h \mathrm{CR}$ with partial hematologic recovery, $C R i \mathrm{CR}$ with incomplete hematologic recovery

\section{Future Perspectives}

Despite the high efficacy of CAR T cell and BiAb treatments, several hurdles continue to hamper their broader applicability. To tackle treatment-related toxicity, which has been especially problematic for CAR T cells (see Table 1), many approaches have been developed to improve their safety by making them more controllable (see Table 2). In addition, many CAR T cell- or BiAb-treated patients relapse due to antigen escape and, in the case of CAR T cells, limited persistence of the transferred $\mathrm{T}$ cells. This, alongside tumor antigen heterogeneity, has prompted the development of modular approaches combining $\mathrm{T}$ cells engineered with a CAR-like synthetic receptor and $\mathrm{BiAb}$ adapters targeting this receptor and a tumor antigen (see Table 2). These have the flexibility to redirect engineered $\mathrm{T}$ cells toward multiple targets [82].

Among these platforms are the universal CAR (UniCAR) [83•], split universal and programmable (SUPRA) CAR [84•], switch CAR [85•], and the synthetic agonistic receptor (SAR) developed by our lab (Fig. 1d) [86 ]. The activity of the modular CAR T cell can be controlled by the affinities of the two 


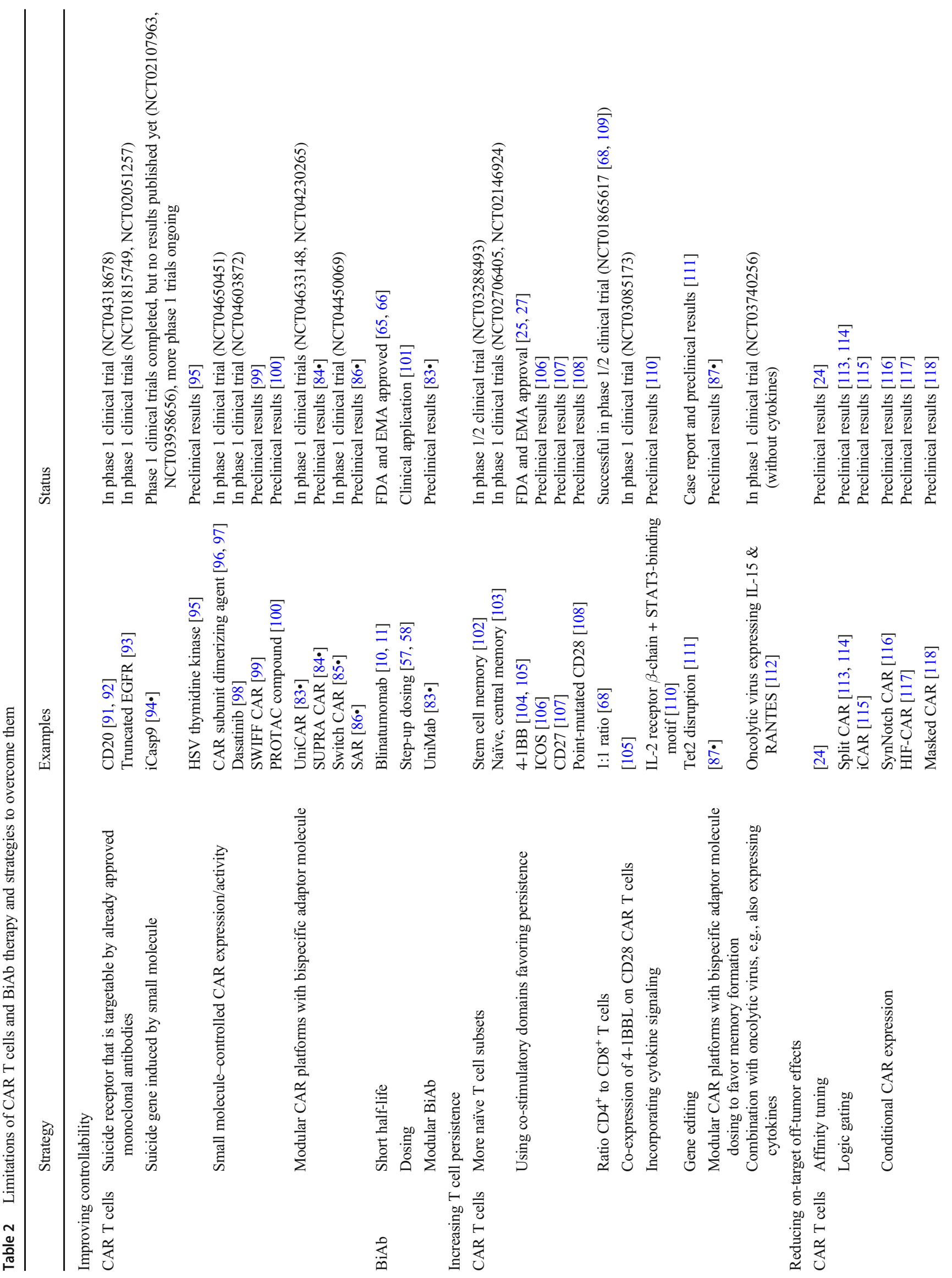




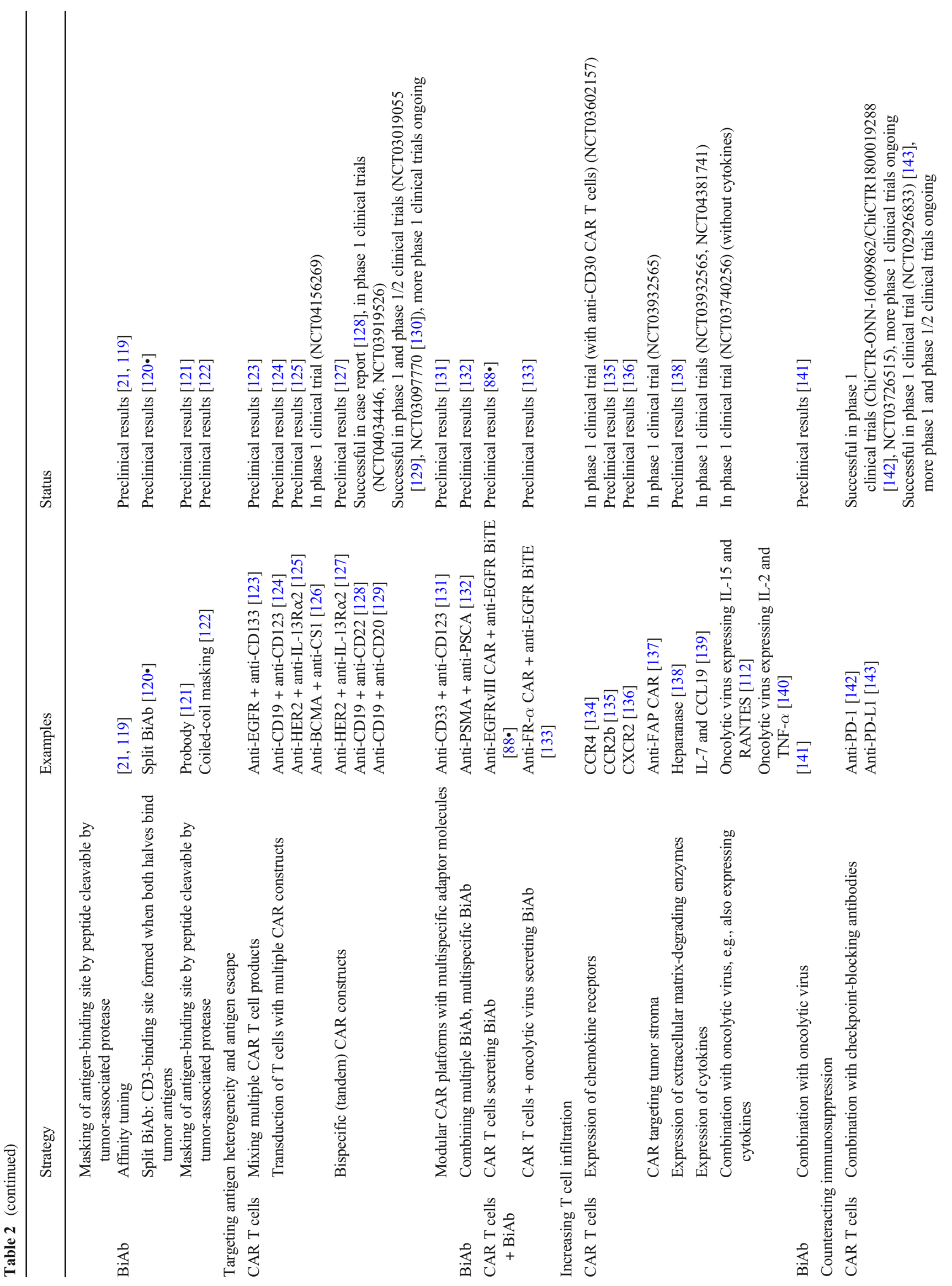




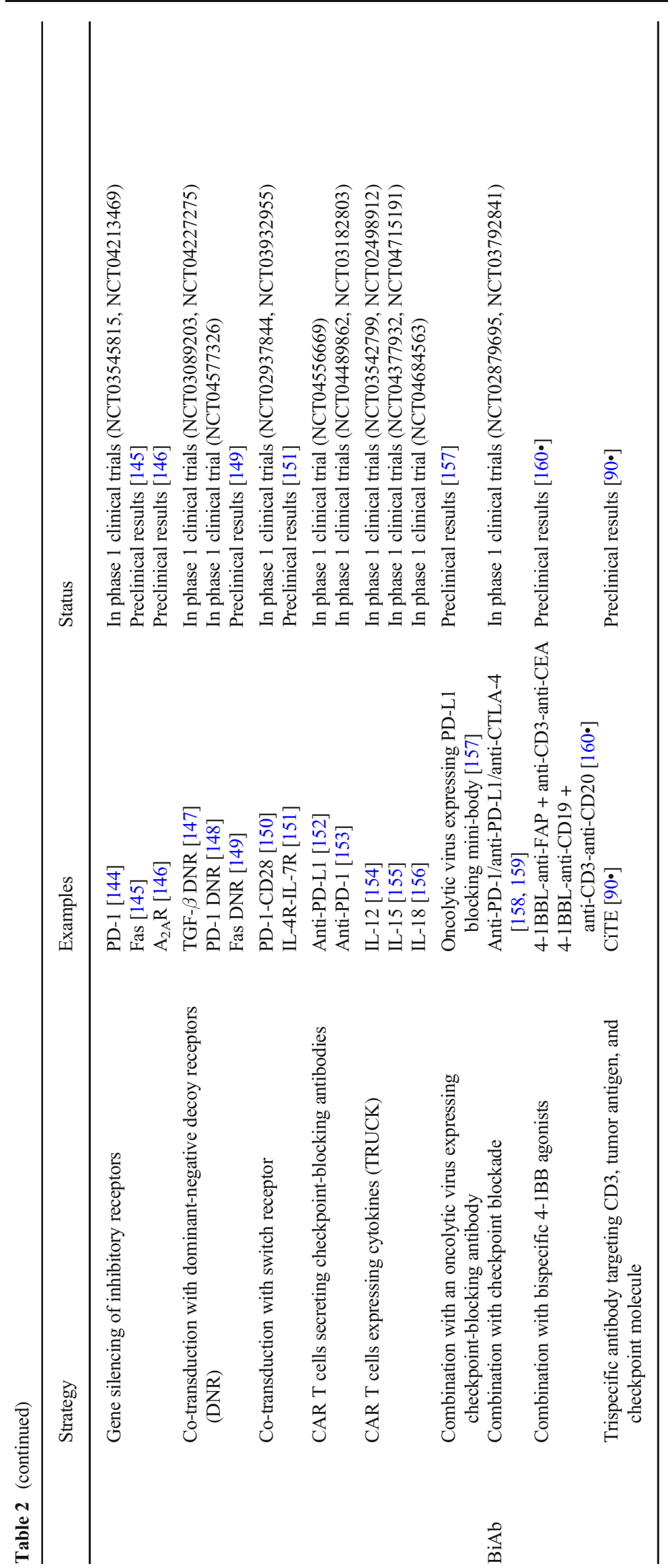


binding sites, as well as the half-life and dosing of the BiAb to limit side effects while retaining antitumor efficacy.

In addition, multiple tumor antigens can be simultaneously or sequentially targeted to address antigen heterogeneity and reduce antigen escape [82]. Moreover, by administering decoys for the CAR adaptors, their activity can be controlled even more tightly [84•]. Interestingly, Viaud et al. could enhance memory $\mathrm{T}$ cell formation by including "rest" phases between dosing cycles of the CAR adapter [87॰]. It is important to note that while advantageous in terms of controllability, short half-life formats of $\mathrm{BiAb}$ mean that regular infusions will be required. Combining CAR T cells and BiAb will likely present hurdles in the form of practicality and cost. Therefore, CAR adaptors will most practically be useful in the context of an "off-the-shelf" universal allogeneic CAR T cell line that can be combined with different adaptors for different tumor antigens.

Translating the success of BiAb and CAR T cell therapies to solid cancer indications poses additional challenges. As a result, attempts to improve $\mathrm{T}$ cell recruitment into the tumor render $\mathrm{T}$ cells more resistant to the immunosuppressive tumor microenvironment and target antigen heterogeneity among tumor cells are currently underway (see Table 2). One noteworthy strategy presented by Choi and colleagues employs engineered CAR $\mathrm{T}$ cells to secrete BiAb targeting a second tumor antigen to treat glioblastoma. They could show this to be a promising approach in a mouse model which shows antigen-negative relapse when CAR T cells alone are employed [88 ${ }^{\circ}$. Trafficking of CAR T cells may be enhanced by equipping them with, e.g., chemokine receptors for chemokines expressed in the tumor [89॰]. Trispecific antibodies targeting CD3, a tumor antigen, and a checkpoint molecule have been shown to counteract immunosuppression [90॰].

Table 2 provides an overview of the current strategies being developed to overcome the aforementioned challenges of CAR T cells and BiAb.

\section{Conclusion}

Despite the apparent overlap between CAR T cell and BiAb approaches (such as their application to target the same antigen for some of the same indications), it remains clear that both therapies offer distinct benefits. The emergence of treatments that combine the best of both the CAR and BiAb worlds highlights this, as shown by SAR T cells that utilize BiAb to enable selective and modular control over T cell activation.

Nevertheless, both CAR and BiAb approaches continue to be developed in their own right, with advancements addressing the shortcomings of either approach. Combining BiAb with bispecific 4-1BB agonists is one such example, where the lack of a co-stimulatory signal 2 is effectively overcome. For CAR T cells, various approaches have been developed by either limiting their activation to the tumor microenvironment, like the hypoxia-inducible factor (HIF) or synthetic Notch (SynNotch) CAR, or by making their activation more controllable from the outside, e.g., by administering small molecules or antibodies to activate or inhibit CAR T cell activity.

Due to the speed at which both therapies have gained regulatory approval, mechanistic insights into the drivers of treatment efficacy, disease relapse, and treatmentrelated toxicities are only now being uncovered. Translating these insights from bench to bedside in a timely and effective manner will be important to achieve greater patient benefit.

Abbreviations $\mathrm{A}_{2 \mathrm{~A}}$, Adenosine 2A Receptor; BCMA, B Cell Maturation Antigen; CCL, C-C Motif Chemokine Ligand; CCR, C-C Motif Chemokine Receptor; CEA, Carcinoembryonic Antigen; CiTE, Checkpoint inhibitory T cell-Engaging; CTLA-4, Cytotoxic T Lymphocyte Associated Protein 4; CXCR, C-X-C Motif Chemokine Receptor; DNR, Double-Negative Receptor; EGFR, Epidermal Growth Factor Receptor; EGFRvIII, EGFR Variant 3; FR- $\alpha$, Folate Receptor $\alpha$; HER2, Human Epidermal Growth Factor Receptor 2; HIF, HypoxiaInducible Factor; HSV, Herpes Simplex Virus; iCAR, inhibitory CAR; iCasp9, inducible Caspase 9; ICOS, Inducible T Cell Costimulatory; PD1, Programmed Cell Death Protein 1; PD-L1, Programmed Cell Death 1 Ligand 1; PROTAC:, Proteolysis-Targeting Chimaera; PSCA, Prostate Stem Cell Antigen; PSMA, Prostate Specific Membrane Antigen; RANTES, Regulated upon Activation, Normal T cell Expressed and Presumably Secreted; STAT3, Signal Transducer and Activator of Transcription 3; SWIFF, Switch-Off CAR; SynNotch, Synthetic Notch; TET2, Tet Methylcytosine Dioxygenase 2; TGF- $\beta$, Transforming Growth Factor $\beta$; TNF, Tumor Necrosis Factor; TRUCK, T Cells Redirected for Antigen-Unrestricted Cytokine-Initiated Killing

Funding Open Access funding enabled and organized by Projekt DEAL. SK is supported by the Marie-Sklodowska-Curie Program Training Network for the Immunotherapy of Cancer funded by the H2020 Program of the European Union (Grant 641549) and the MarieSklodowska-Curie Program Training Network for the Optimizing adoptive T cell therapy funded by the H2020 Program of the European Union (Grant 641549 and 955575); the Hector Foundation; the International Doctoral Program i Target: Immunotargeting of Cancer funded by the Elite Network of Bavaria (SK and SE); Melanoma Research Alliance Grants 409510 (to SK); the Else Kröner-Fresenius-Stiftung (SK); the German Cancer Aid (SK); the Ernst-Jung-Stiftung (SK); LMU Munich's Institutional Strategy LMUexcellent within the framework of the German Excellence Initiative (SE and SK); the Bundesministerium für Bildung und Forschung Project Oncoattract and CONTRACT (SE and SK); the European Research Council Grant 756017, ARMOR-T (to SK), the German Research Foundation (DFG to SK); and the JoséCarreras Foundation (to SK). The work was further supported by a German Research Council (DFG) grant provided within the Sonderforschungsbereich SFB 1243 (MaS) and the Wilhelm-Sander Stiftung (MaS). MaS has received industry research support from Amgen, Gilead, Miltenyi, MorphoSys, Roche, and Seattle Genetics.

\section{Declarations}

Conflict of Interest Melanie Schwerdtfeger, Mohamed-Reda Benmebarek, and Vincenzo Desiderio declare that they have no conflict of interest. 
Sebastian Kobold has received TCR2 for consultancy honoraria for education and consultancy from Novartis and GSK. SK has received research support from TCR2 Inc., Boston, and Arcus Biosciences, USA. S K and SE have licensed IP to TCR2 Inc. MaS has served as a consultant/advisor to Amgen, BMS, Celgene, Gilead, Pfizer, Novartis, and Roche. She sits on the advisory boards of Amgen, Celgene, Gilead, Janssen, Novartis, Pfizer, and Seattle Genetics and serves on the speakers' bureau at Amgen, Celgene, Gilead, Janssen, and Pfizer.

Human and Animal Rights and Informed Consent This article does not contain any studies with human or animal subjects performed by any of the authors.

Open Access This article is licensed under a Creative Commons Attribution 4.0 International License, which permits use, sharing, adaptation, distribution and reproduction in any medium or format, as long as you give appropriate credit to the original author(s) and the source, provide a link to the Creative Commons licence, and indicate if changes were made. The images or other third party material in this article are included in the article's Creative Commons licence, unless indicated otherwise in a credit line to the material. If material is not included in the article's Creative Commons licence and your intended use is not permitted by statutory regulation or exceeds the permitted use, you will need to obtain permission directly from the copyright holder. To view a copy of this licence, visit http://creativecommons.org/licenses/by/4.0/.

\section{References}

Papers of particular interest, published recently, have been highlighted as:

- Of importance

•. Of major importance

1. Lesch S, Benmebarek M-R, Cadilha BL, Stoiber S, Subklewe M, Endres S, et al. Determinants of response and resistance to CAR T cell therapy. Semin Cancer Biol. 2020;65:80-90. https://doi.org/ 10.1016/j.semcancer.2019.11.004 Review about response, resistance, and current obstacles in CAR $\mathrm{T}$ cell therapy.

2.• Goebeler M-E, Bargou RC. T cell-engaging therapies - BiTEs and beyond. Nat Rev Clin Oncol. 2020;17:418-34. https://doi. org/10.1038/s41571-020-0347-5 Excellent review on BiTEs, also in relation to CAR T cells.

3.• Strohl WR, Naso M. Bispecific T-cell redirection versus chimeric antigen receptor (CAR)-T cells as approaches to kill cancer cells. Antibodies (Basel, Switzerland). 2019. https://doi.org/10.3390/ antib8030041 Detailed review comparing CAR T and BiAb.

4. Ellerman D. Bispecific T-cell engagers: towards understanding variables influencing the in vitro potency and tumor selectivity and their modulation to enhance their efficacy and safety. Methods (San Diego Calif). 2019;154:102-17. https://doi.org/ 10.1016/j.ymeth.2018.10.026.

5. Benmebarek M-R, Karches CH, Cadilha BL, Lesch S, Endres S, Kobold S. Killing mechanisms of chimeric antigen receptor (CAR) T cells. Int J Mol Sci. 2019. https://doi.org/10.3390/ ijms20061283 Review on the mechanisms of CAR T cell killing.

6. Labrijn AF, Janmaat ML, Reichert JM, Parren PWHI. Bispecific antibodies: a mechanistic review of the pipeline. Nat Rev Drug Discov. 2019;18:585-608. https://doi.org/10.1038/s41573-019-
0028-1 Comprehensive review on BiAb and overview of ongoing clinical trials.

7. Clynes RA, Desjarlais JR. Redirected T cell cytotoxicity in cancer therapy. Annu Rev Med. 2019;70:437-50. https://doi.org/10. 1146/annurev-med-062617-035821.

8. Thakur A, Huang M, Lum LG. Bispecific antibody based therapeutics: strengths and challenges. Blood Rev. 2018;32:339-47. https://doi.org/10.1016/j.blre.2018.02.004.

9. Roopenian DC, Akilesh S. FcRn: the neonatal Fc receptor comes of age. Nat Rev Immunol. 2007;7:715-25. https://doi.org/10. 1038/nri2155.

10. Klinger M, Brandl C, Zugmaier G, Hijazi Y, Bargou RC, Topp MS, et al. Immunopharmacologic response of patients with Blineage acute lymphoblastic leukemia to continuous infusion of T cell-engaging CD19/CD3-bispecific BiTE antibody blinatumomab. Blood. 2012;119:6226-33. https://doi.org/10. 1182/blood-2012-01-400515.

11. Zhu M, Wu B, Brandl C, Johnson J, Wolf A, Chow A, et al. Blinatumomab, a bispecific T-cell engager (BiTE®) for CD-19 targeted cancer immunotherapy: clinical pharmacology and its implications. Clin Pharmacokinet. 2016;55:1271-88. https://doi. org/10.1007/s40262-016-0405-4.

12. Arvedson TL, Balazs M, Bogner P, Black K, Graham K, Henn A, et al. Abstract 55: Generation of half-life extended anti-CD33 BiTE® antibody constructs compatible with once-weekly dosing. In: Proceedings: AACR Annual Meeting, vol. 07012017. Washington, DC: American Association for Cancer Research; 2017. p. 55. https://doi.org/10.1158/1538-7445.AM2017-55.

13. Ruf $\mathrm{P}$, Kluge M, Jäger M, Burges A, Volovat C, Heiss MM, et al. Pharmacokinetics, immunogenicity and bioactivity of the therapeutic antibody catumaxomab intraperitoneally administered to cancer patients. Br J Clin Pharmacol. 2010;69:617-25. https:// doi.org/10.1111/j.1365-2125.2010.03635.x.

14. Demarest SJ, Glaser SM. Antibody therapeutics, antibody engineering, and the merits of protein stability. Current opinion in drug discovery \& development. 2008;11:675-87.

15. Rader C. Bispecific antibodies in cancer immunotherapy. Curr Opin Biotechnol. 2019;65:9-16. https://doi.org/10.1016/j.copbio. 2019.11.020 Review highlighting novel developments in BiAb for cancer immunotherapy.

16. Mandikian D, Takahashi N, Lo AA, Li J, Eastham-Anderson J, Slaga D, et al. Relative target affinities of T-cell-dependent bispecific antibodies determine biodistribution in a solid tumor mouse model. Mol Cancer Ther. 2018;17:776-85. https://doi. org/10.1158/1535-7163.MCT-17-0657.

17. Leong SR, Sukumaran S, Hristopoulos M, Totpal K, Stainton S, Lu E, et al. An anti-CD3/anti-CLL-1 bispecific antibody for the treatment of acute myeloid leukemia. Blood. 2017;129:609-18. https://doi.org/10.1182/blood-2016-08-735365.

18. Lopez-Albaitero A, Xu H, Guo H, Wang L, Wu Z, Tran H, et al. Overcoming resistance to HER2-targeted therapy with a novel HER2/CD3 bispecific antibody. Oncoimmunology. 2017;6: e1267891. https://doi.org/10.1080/2162402X.2016.1267891.

19. Ahmed M, Cheng M, Cheung IY, Cheung NK. Human derived dimerization tag enhances tumor killing potency of a T-cell engaging bispecific antibody. Oncoimmunology. 2015;4:e989776. https://doi.org/10.4161/2162402X.2014.989776.

20. Slaga D, Ellerman D, Lombana TN, Vij R, Li J, Hristopoulos M, et al. Avidity-based binding to HER2 results in selective killing of HER2-overexpressing cells by anti-HER2/CD3. Sci Transl Med. 2018;10:eaat5775. https://doi.org/10.1126/scitranslmed.aat5775.

21. Zafra C, de Balazs M, Fajardo F, Liang L, Zhong W, Henn A, et al. Preclinical characterization of AMG 424, a novel humanized $\mathrm{T}$ cell-recruiting bispecific anti-CD3/CD38 antibody. Blood. 2017;130(Supplement 1):500. https://doi.org/10.1182/BLOOD. V130.SUPPL_1.500.500. 
22. ClinicalTrials.gov. search terms: condition or disease: "cancer"; intervention: "bispecific AND antibody AND cd3"; status: recruitment: recruiting, enrolling by invitation, active not recruiting. https://clinicaltrials.gov. Accessed 9 Oct 2020.

23. Stoiber S, Cadilha BL, Benmebarek M-R, Lesch S, Endres S, Kobold S. Limitations in the design of chimeric antigen receptors for cancer therapy. Cells. 2019. https://doi.org/10.3390/ cells 8050472 Review on contribution of individual CAR components to CAR $\mathrm{T}$ cell functionality.

24. Liu X, Jiang S, Fang C, Yang S, Olalere D, Pequignot EC, et al. Affinity-tuned ErbB2 or EGFR chimeric antigen receptor T cells exhibit an increased therapeutic index against tumors in mice. Cancer Res. 2015;75:3596-607. https://doi.org/10.1158/00085472.CAN-15-0159.

25. U.S. Food and Drug Administration. KYMRIAH (tisagenlecleucel). https://www.fda.gov/vaccines-bloodbiologics/cellular-gene-therapy-products/kymriahtisagenlecleucel. Accessed 4 Oct 2020.

26. U.S. Food and Drug Administration. YESCARTA (axicabtagene ciloleucel). https://www.fda.gov/vaccines-blood-biologics/ cellular-gene-therapy-products/yescarta-axicabtagene-ciloleucel. Accessed 4 Oct 2020.

27. European Medicines Agency. Kymriah. https://www.ema.europa. $\mathrm{eu} / \mathrm{en} / \mathrm{medicines} / \mathrm{human} / \mathrm{EPAR} / \mathrm{kymriah}$. Accessed 4 Oct 2020.

28. European Medicines Agency. Yescarta. https://www.ema.europa. eu/en/medicines/human/EPAR/yescarta. Accessed 4 Oct 2020.

29. European Medicines Agency. Tecartus. https://www.ema.europa. eu/en/medicines/human/EPAR/tecartus. Accessed 25 Feb 2021.

30. U.S. Food and Drug Administration. TECARTUS (brexucabtagene autoleucel). https://www.fda.gov/vaccinesblood-biologics/cellular-gene-therapy-products/tecartusbrexucabtagene-autoleucel. Accessed 25 Feb 2021.

31. Wang M, Munoz J, Goy A, Locke FL, Jacobson CA, Hill BT, et al. KTE-X19 CAR T-cell therapy in relapsed or refractory mantle-cell lymphoma. N Engl J Med. 2020;382:1331-42. https://doi.org/10.1056/NEJMoa1914347.

32. ClinicalTrials.gov. search terms: condition or disease: "cancer"; intervention: "chimeric AND antigen AND receptor AND t AND cell"; status: recruitment: recruiting, enrolling by invitation, active not recruiting. https://clinicaltrials.gov. Accessed 9 Oct 2020.

33. ClinicalTrials.gov. search terms: condition or disease: "cancer"; intervention: "chimeric AND antigen AND receptor AND t AND cell"; status: recruitment: recruiting, enrolling by invitation, active not recruiting; study start: from 01/01/2020. https://clinicaltrials.gov. Accessed 9 Oct 2020.

34. Munshi NC, Anderson LD, Shah N, Madduri D, Berdeja J, Lonial $\mathrm{S}$, et al. Idecabtagene vicleucel in relapsed and refractory multiple myeloma. N Engl J Med. 2021;384:705-16. https://doi.org/10. 1056/NEJMoa2024850.

35. Lindner SE, Johnson SM, Brown CE, Wang LD. Chimeric antigen receptor signaling: functional consequences and design implications. Sci Adv. 2020;6:eaaz3223. https://doi.org/10.1126/ sciadv.aaz3223.

36. Offner S, Hofmeister R, Romaniuk A, Kufer P, Baeuerle PA. Induction of regular cytolytic $\mathrm{T}$ cell synapses by bispecific single-chain antibody constructs on MHC class I-negative tumor cells. Mol Immunol. 2006;43:763-71. https://doi.org/10.1016/j. molimm.2005.03.007.

37. Davenport AJ, Cross RS, Watson KA, Liao Y, Shi W, Prince HM, et al. Chimeric antigen receptor $\mathrm{T}$ cells form nonclassical and potent immune synapses driving rapid cytotoxicity. Proc Natl Acad Sci U S A. 2018;115:E2068-76. https://doi.org/10.1073/ pnas. 1716266115 .

38. Künkele A, Johnson AJ, Rolczynski LS, Chang CA, Hoglund V, Kelly-Spratt KS, et al. Functional tuning of CARs reveals signaling threshold above which CD8+ CTL antitumor potency is attenuated due to cell Fas-FasL-dependent AICD. Cancer Immunol Res. 2015;3:368-79. https://doi.org/10.1158/23266066.CIR-14-0200.

39. Darcy PK, Kershaw MH, Trapani JA, Smyth MJ. Expression in cytotoxic $\mathrm{T}$ lymphocytes of a single-chain anti-carcinoembryonic antigen antibody. Redirected Fas ligand-mediated lysis of colon carcinoma. Eur J Immunol. 1998;28:1663-72. https://doi.org/10. 1002/(SICI)1521-4141(199805)28:05<1663::AIDIMMU1663>3.0.CO;2-L.

40. Haas C, Krinner E, Brischwein K, Hoffmann P, Lutterbüse R, Schlereth B, et al. Mode of cytotoxic action of T cell-engaging BiTE antibody MT110. Immunobiology. 2009;214:441-53. https://doi.org/10.1016/j.imbio.2008.11.014.

41. Ross SL, Sherman M, McElroy PL, Lofgren JA, Moody G, Baeuerle PA, et al. Bispecific T cell engager (BiTE®) antibody constructs can mediate bystander tumor cell killing. PLoS One. 2017;12:e0183390. https://doi.org/10.1371/journal.pone. 0183390

42. Hong LK, Chen Y, Smith CC, Montgomery SA, Vincent BG, Dotti G, et al. CD30-redirected chimeric antigen receptor $\mathrm{T}$ cells target CD30+ and CD30- embryonal carcinoma via antigendependent and Fas/FasL interactions. Cancer Immunol Res. 2018;6:1274-87. https://doi.org/10.1158/2326-6066.CIR-180065 .

43. Brossart $\mathrm{P}$. The role of antigen spreading in the efficacy of immunotherapies. Clin Cancer Res. 2020;26:4442-7. https://doi.org/10. 1158/1078-0432.CCR-20-0305.

44. Beatty GL, Haas AR, Maus MV, Torigian DA, Soulen MC, Plesa $\mathrm{G}$, et al. Mesothelin-specific chimeric antigen receptor mRNAengineered $\mathrm{T}$ cells induce anti-tumor activity in solid malignancies. Cancer Immunol Res. 2014;2:112-20. https://doi.org/10. 1158/2326-6066.CIR-13-0170.

45. Kim RH, Plesa G, Gladney W, Kulikovskaya I, Levine BL, Lacey $\mathrm{SF}$, et al. Effect of chimeric antigen receptor (CAR) T cells on clonal expansion of endogenous non-CAR T cells in patients (pts) with advanced solid cancer. JCO. 2017;35:3011. https://doi.org/ 10.1200/JCO.2017.35.15_suppl.3011.

46. Dao T, Pankov D, Scott A, Korontsvit T, Zakhaleva V, Xu Y, et al. Therapeutic bispecific T-cell engager antibody targeting the intracellular oncoprotein WT1. Nat Biotechnol. 2015;33:107986. https://doi.org/10.1038/nbt.3349.

47. Slaney CY, Wang P, Darcy PK, Kershaw MH. CARs versus BiTEs: a comparison between T cell-redirection strategies for cancer treatment. Cancer Discov. 2018;8:924-34. https://doi.org/10. 1158/2159-8290.CD-18-0297 Review comparing CAR T cells and BiAb.

48. Yang Y, Lin T, Jacoby E, Qin H, Gardner EG, Chien CD, et al. CD4 CAR T cells mediate CD8-like cytotoxic anti-leukemic effects resulting in leukemic clearance and are less susceptible to attenuation by endogenous TCR activation than CD8 CAR T cells. Blood. 2015;126:100. https://doi.org/10.1182/blood.V126. 23.100.100.

49. Rafiq S, Hackett CS, Brentjens RJ. Engineering strategies to overcome the current roadblocks in CAR T cell therapy. Nature reviews. Clin Oncol. 2020;17:147-67. https://doi.org/10.1038/ s41571-019-0297-y Detailed review on obstacles in CAR T cell therapy and strategies to overcome them.

50. Choi BD, Gedeon PC, Sanchez-Perez L, Bigner DD, Sampson JH. Regulatory $\mathrm{T}$ cells are redirected to kill glioblastoma by an EGFRvIII-targeted bispecific antibody. Oncoimmunology. 2013;2:e26757. https://doi.org/10.4161/onci.26757.

51. Wang X, Rivière I. Clinical manufacturing of CAR T cells: foundation of a promising therapy. Mol Ther Oncolytics. 2016;3: 16015. https://doi.org/10.1038/mto.2016.15. 
52. Neelapu SS, Locke FL, Bartlett NL, Lekakis LJ, Miklos DB, Jacobson CA, et al. Axicabtagene ciloleucel CAR T-cell therapy in refractory large B-cell lymphoma. N Engl J Med. 2017;377: 2531-44. https://doi.org/10.1056/NEJMoa1707447.

53. Schuster SJ, Bishop MR, Tam CS, Waller EK, Borchmann P, McGuirk JP, et al. Tisagenlecleucel in adult relapsed or refractory diffuse large B-cell lymphoma. N Engl J Med. 2019;380:45-56. https://doi.org/10.1056/NEJMoa1804980.

54. Grupp SA, Kalos M, Barrett D, Aplenc R, Porter DL, Rheingold $\mathrm{SR}$, et al. Chimeric antigen receptor-modified $\mathrm{T}$ cells for acute lymphoid leukemia. N Engl J Med. 2013;368:1509-18. https:// doi.org/10.1056/NEJMoa1215134.

55. Stadtmauer EA, Fraietta JA, Davis MM, Cohen AD, Weber KL, Lancaster E, et al. CRISPR-engineered T cells in patients with refractory cancer. Science. 2020;367:eaba7365. https://doi.org/ 10.1126/science.aba7365.

56. Lee DW, Santomasso BD, Locke FL, Ghobadi A, Turtle CJ, Brudno JN, et al. ASTCT consensus grading for cytokine release syndrome and neurologic toxicity associated with immune effector cells. Biol Blood Marrow Transplan: J American Society Blood Marrow Transplant. 2019;25:625-38. https://doi.org/10. 1016/j.bbmt.2018.12.758.

57. Goebeler M-E, Knop S, Viardot A, Kufer P, Topp MS, Einsele H, et al. Bispecific T-cell engager (BiTE) antibody construct blinatumomab for the treatment of patients with relapsed/ refractory non-Hodgkin lymphoma: final results from a phase I study. J Clin Oncol. 2016;34:1104-11. https://doi.org/10.1200/ JCO.2014.59.1586.

58. Viardot A, Goebeler M-E, Hess G, Neumann S, Pfreundschuh M, Adrian N, et al. Phase 2 study of the bispecific T-cell engager (BiTE) antibody blinatumomab in relapsed/refractory diffuse large B-cell lymphoma. Blood. 2016;127:1410-6. https://doi. org/10.1182/blood-2015-06-651380.

59. Brudno JN, Kochenderfer JN. Recent advances in CAR T-cell toxicity: mechanisms, manifestations and management. Blood Rev. 2019;34:45-55. https://doi.org/10.1016/j.blre.2018.11.002.

60. Velasquez MP, Bonifant CL, Gottschalk S. Redirecting T cells to hematological malignancies with bispecific antibodies. Blood. 2018;131:30-8. https://doi.org/10.1182/blood-2017-06-741058.

61. Keating AK, Gossai N, Phillips CL, Maloney K, Campbell K, Doan A, et al. Reducing minimal residual disease with blinatumomab prior to HCT for pediatric patients with acute lymphoblastic leukemia. Blood Adv. 2019;3:1926-9. https://doi.org/ 10.1182/bloodadvances.2018025726.

62. Pulsipher MA, Are CAR. T cells better than antibody or HCT therapy in B-ALL? Hematol Am Soc Hemat Educ Program. 2018;2018:16-24. https://doi.org/10.1182/asheducation-2018.1. 16.

63. Ran T, Eichmüller SB, Schmidt P, Schlander M. Cost of decentralized CAR T-cell production in an academic nonprofit setting. Int J Cancer. 2020;147:3438-45. https://doi.org/10. 1002/ijc. 33156 .

64. Institut für Qualität und Wirtschaftlichkeit im Gesundheitswesen (IQWiG). Blinatumomab (akute lymphatische Leukämie: Erwachsene mit minimaler Resterkrankung). 2019. https://www. iqwig.de/download/G19-08 Blinatumomab ALL-Erwachsenemit-minimaler-Resterkrankung_Bewertung-35a-Absatz-1-Satz11-SGB-V_V1-0.pdf. Accessed 14 Oct 2020.

65. U.S. Food and Drug Administration. FDA granted accelerated approval to blinatumomab (Blincyto, Amgen Inc.) for the treatment of adult and pediatric patients with B-cell precursor acute lymphoblastic leukemia. https://www.fda.gov/drugs/resourcesinformation-approved-drugs/fda-granted-accelerated-approvalblinatumomab-blincyto-amgen-inc-treatment-adult-and-pediatric. Accessed 4 Oct 2020.
66. European Medicines Agency. Blincyto. https://www.ema.europa. eu/en/medicines/human/EPAR/blincyto. Accessed 4 Oct 2020.

67. Davila ML, Riviere I, Wang X, Bartido S, Park J, Curran K, et al. Efficacy and toxicity management of 19-28z CAR T cell therapy in B cell acute lymphoblastic leukemia. Sci Transl Med. 2014;6: 224ra25. https://doi.org/10.1126/scitranslmed.3008226.

68. Turtle CJ, Hanafi L-A, Berger C, Gooley TA, Cherian S, Hudecek $\mathrm{M}$, et al. CD19 CAR-T cells of defined CD4+:CD8+ composition in adult B cell ALL patients. J Clin Investig. 2016;126:2123-38. https://doi.org/10.1172/JCI85309.

69. Park JH, Rivière I, Gonen M, Wang X, Sénéchal B, Curran KJ, et al. Long-term follow-up of CD19 CAR therapy in acute lymphoblastic leukemia. N Engl J Med. 2018;378:449-59. https://doi. org/10.1056/NEJMoa1709919.

70. Maude SL, Frey N, Shaw PA, Aplenc R, Barrett DM, Bunin NJ, et al. Chimeric antigen receptor T cells for sustained remissions in leukemia. N Engl J Med. 2014;371:1507-17. https://doi.org/10. 1056/NEJMoa1407222.

71. Maude SL, Laetsch TW, Buechner J, Rives S, Boyer M, Bittencourt $\mathrm{H}$, et al. Tisagenlecleucel in children and young adults with B-cell lymphoblastic leukemia. N Engl J Med. 2018;378: 439-48. https://doi.org/10.1056/NEJMoa1709866.

72. Grupp SA, Maude SL, Shaw PA, Aplenc R, Barrett DM, Callahan $C$, et al. Durable remissions in children with relapsed/refractory ALL treated with T cells engineered with a CD19-targeted chimeric antigen receptor (CTL019). Blood. 2015;126:681. https://doi. org/10.1182/blood.V126.23.681.681.

73. Lee DW, Kochenderfer JN, Stetler-Stevenson M, Cui YK, Delbrook C, Feldman SA, et al. T cells expressing CD19 chimeric antigen receptors for acute lymphoblastic leukaemia in children and young adults: a phase 1 dose-escalation trial. Lancet. 2015;385:517-28. https://doi.org/10.1016/S0140-6736(14) 61403-3.

74. Kochenderfer JN, Dudley ME, Kassim SH, Somerville RPT, Carpenter RO, Stetler-Stevenson M, et al. Chemotherapyrefractory diffuse large B-cell lymphoma and indolent B-cell malignancies can be effectively treated with autologous $\mathrm{T}$ cells expressing an anti-CD19 chimeric antigen receptor. JCO. 2015;33: 540-9. https://doi.org/10.1200/JCO.2014.56.2025.

75. Schuster SJ, Svoboda J, Chong EA, Nasta SD, Mato AR, Anak Ö, et al. Chimeric antigen receptor T cells in refractory B-cell lymphomas. N Engl J Med. 2017;377:2545-54. https://doi.org/10. 1056/NEJMoa1708566.

76. Topp MS, Gökbuget N, Zugmaier G, Klappers P, Stelljes M, Neumann S, et al. Phase II trial of the anti-CD19 bispecific T cell-engager blinatumomab shows hematologic and molecular remissions in patients with relapsed or refractory B-precursor acute lymphoblastic leukemia. J Clin Oncol. 2014;32:4134-40. https:// doi.org/10.1200/JCO.2014.56.3247.

77. Topp MS, Gökbuget N, Stein AS, Zugmaier G, O'Brien S, Bargou $\mathrm{RC}$, et al. Safety and activity of blinatumomab for adult patients with relapsed or refractory B-precursor acute lymphoblastic leukaemia: a multicentre, single-arm, phase 2 study. Lancet Oncol. 2015;16:57-66. https://doi.org/10.1016/S1470-2045(14)71170-2.

78. Kantarjian H, Stein A, Gökbuget N, Fielding AK, Schuh AC, Ribera J-M, et al. Blinatumomab versus chemotherapy for advanced acute lymphoblastic leukemia. N Engl J Med. 2017;376: 836-47. https://doi.org/10.1056/NEJMoa1609783.

79. Martinelli G, Boissel N, Chevallier P, Ottmann O, Gökbuget N, Topp MS, et al. Complete hematologic and molecular response in adult patients with relapsed/refractory Philadelphia chromosomepositive B-precursor acute lymphoblastic leukemia following treatment with blinatumomab: results from a phase II, singlearm, multicenter study. J Clin Oncol. 2017;35:1795-802. https:// doi.org/10.1200/JCO.2016.69.3531. 
80. von Stackelberg A, Locatelli F, Zugmaier G, Handgretinger R, Trippett TM, Rizzari C, et al. Phase I/phase II study of blinatumomab in pediatric patients with relapsed/refractory acute lymphoblastic leukemia. JCO. 2016;34:4381-9. https://doi.org/ 10.1200/JCO.2016.67.3301.

81. Jabbour E, Düll J, Yilmaz M, Khoury JD, Ravandi F, Jain N, et al. Outcome of patients with relapsed/refractory acute lymphoblastic leukemia after blinatumomab failure: no change in the level of CD19 expression. Am J Hematol. 2018;93:371-4. https://doi. org/10.1002/ajh.24987.

82. Darowski D, Kobold S, Jost C, Klein C. Combining the best of two worlds: highly flexible chimeric antigen receptor adaptor molecules (CAR-adaptors) for the recruitment of chimeric antigen receptor T cells. mAbs. 2019;11:621-31. https://doi.org/10.1080/ 19420862.2019.1596511.

83. Bachmann M. The UniCAR system: A modular CAR T cell approach to improve the safety of CAR T cells. Immunol Lett. 2019;211:13-22. https://doi.org/10.1016/j.imlet.2019.05.003 Review describing the modular universal CAR $T$ cell and BiAb approaches.

84. Cho JH, Collins JJ, Wong WW. Universal chimeric antigen receptors for multiplexed and logical control of $\mathrm{T}$ cell responses. Cell. 2018;173:1426-1438.e11. https://doi.org/10.1016/j.cell. 2018.03.038 Presentation of the modular split, universal, and programmable (SUPRA) CAR system.

85. Rodgers DT, Mazagova M, Hampton EN, Cao Y, Ramadoss NS, Hardy IR, et al. Switch-mediated activation and retargeting of CAR-T cells for B-cell malignancies. Proc Natl Acad Sci U S A. 2016;113:E459-68. https://doi.org/10.1073/pnas.1524155113 Report of modular switch CAR approach.

86. Karches CH, Benmebarek M-R, Schmidbauer ML, Kurzay M, Klaus R, Geiger M, et al. Bispecific antibodies enable synthetic agonistic receptor-transduced $\mathrm{T}$ cells for tumor immunotherapy. Clin Cancer Res. 2019;25:5890-900. https://doi.org/10.1158/ 1078-0432.CCR-18-3927 Description of the modular synthetic agonistic receptor platform.

87. Viaud S, Ma JSY, Hardy IR, Hampton EN, Benish B, Sherwood $\mathrm{L}$, et al. Switchable control over in vivo CAR T expansion, B cell depletion, and induction of memory. Proc Natl Acad Sci U S A. 2018;115:E10898-E10906. https://doi.org/10.1073/pnas. 1810060115 Report on induction of memory $\mathbf{T}$ cell responses by introducing rest phases into the CAR adapter dosing.

88. Choi BD, Yu X, Castano AP, Bouffard AA, Schmidts A, Larson RC, et al. CAR-T cells secreting BiTEs circumvent antigen escape without detectable toxicity. Nat Biotechnol. 2019;37:1049-58. https://doi.org/10.1038/s41587-019-0192-1 Preventing antigen escape in glioblastoma by combining CAR $T$ cells and a BiTE targeting different antigens.

89. Tokarew N, Ogonek J, Endres S, Bergwelt-Baildon M, von Kobold S. Teaching an old dog new tricks: next-generation CAR T cells. Br J Cancer. 2019;120:26-37. https://doi.org/10. 1038/s41416-018-0325-1 Review describing novel approaches to improve CAR T cell therapy.

90. Herrmann M, Krupka C, Deiser K, Brauchle B, Marcinek A, Ogrinc Wagner A, et al. Bifunctional PD- $1 \times \alpha \mathrm{CD} 3 \times \alpha \mathrm{CD} 33$ fusion protein reverses adaptive immune escape in acute myeloid leukemia. Blood. 2018;132:2484-94. https://doi.org/10.1182/ blood-2018-05-849802 Trispecific antibody targeting immunosuppression.

91. Serafini M, Manganini M, Borleri G, Bonamino M, Imberti L, Biondi A, et al. Characterization of CD20-transduced T lymphocytes as an alternative suicide gene therapy approach for the treatment of graft-versus-host disease. Hum Gene Ther. 2004;15:6376. https://doi.org/10.1089/10430340460732463.

92. Griffioen M, van Egmond EHM, Kester MGD, Willemze R, Falkenburg JHF, Heemskerk MHM. Retroviral transfer of human
CD20 as a suicide gene for adoptive T-cell therapy. Haematologica. 2009;94:1316-20. https://doi.org/10.3324/ haematol.2008.001677.

93. Wang X, Chang W-C, Wong CW, Colcher D, Sherman M, Ostberg JR, et al. A transgene-encoded cell surface polypeptide for selection, in vivo tracking, and ablation of engineered cells. Blood. 2011;118:1255-63. https://doi.org/10.1182/blood-201102-337360.

94. Di Stasi A, Tey S-K, Dotti G, Fujita Y, Kennedy-Nasser A, Martinez $\mathrm{C}$, et al. Inducible apoptosis as a safety switch for adoptive cell therapy. N Engl J Med. 2011;365:1673-83. https://doi. org/10.1056/NEJMoa1106152 Introduction of the inducible caspase 9 system for CAR T cells.

95. Qasim W, Thrasher AJ, Buddle J, Kinnon C, Black ME, Gaspar HB. T cell transduction and suicide with an enhanced mutant thymidine kinase. Gene Ther. 2002;9:824-7. https://doi.org/10. 1038/sj.gt.3301690.

96. Wu C-Y, Roybal KT, Puchner EM, Onuffer J, Lim WA. Remote control of therapeutic $\mathrm{T}$ cells through a small molecule-gated chimeric receptor. Science. 2015:350-aab4077. https://doi.org/10. 1126/science.aab4077.

97. Duong MT, Collinson-Pautz MR. Morschl E, an Lu, Szymanski SP, Zhang M, et al. Two-dimensional regulation of CAR-T cell therapy with orthogonal switches. Mol Ther Oncolytics. 2019;12: 124-37. https://doi.org/10.1016/j.omto.2018.12.009.

98. Mestermann K, Giavridis T, Weber J, Rydzek J, Frenz S, Nerreter $\mathrm{T}$, et al. The tyrosine kinase inhibitor dasatinib acts as a pharmacologic on/off switch for CAR T cells. Sci Transl Med. 2019;11: eaau5907. https://doi.org/10.1126/scitranslmed.aau5907.

99. Juillerat A, Tkach D, Busser BW, Temburni S, Valton J, Duclert A, et al. Modulation of chimeric antigen receptor surface expression by a small molecule switch. BMC Biotechnol. 2019;19:44. https://doi.org/10.1186/s12896-019-0537-3.

100. Lee SM, Kang CH, Choi SU, Kim Y, Hwang JY, Jeong HG, et al. A chemical switch system to modulate chimeric antigen receptor $\mathrm{T}$ cell activity through proteolysis-targeting chimaera technology. ACS Synth Biol. 2020;9:987-92. https://doi.org/10.1021/ acssynbio.9b00476.

101. U.S. Food and Drug Administration. BLINCYTO® (blinatumomab) for injection. 03.2018. https://www.accessdata. fda.gov/drugsatfda_docs/label/2018/125557s013lbl.pdf. Accessed 4 Mar 2021.

102. Xu Y, Zhang M, Ramos CA, Durett A, Liu E, Dakhova O, et al. Closely related T-memory stem cells correlate with in vivo expansion of CAR.CD19-T cells and are preserved by IL-7 and IL-15. Blood. 2014;123:3750-9. https://doi.org/10.1182/blood-2014-01552174.

103. Sommermeyer D, Hudecek M, Kosasih PL, Gogishvili T, Maloney DG, Turtle CJ, et al. Chimeric antigen receptormodified T cells derived from defined CD8+ and CD4+ subsets confer superior antitumor reactivity in vivo. Leukemia. 2016;30: 492-500. https://doi.org/10.1038/leu.2015.247.

104. Milone MC, Fish JD, Carpenito C, Carroll RG, Binder GK, Teachey D, et al. Chimeric receptors containing CD137 signal transduction domains mediate enhanced survival of $\mathrm{T}$ cells and increased antileukemic efficacy in vivo. Mol Ther. 2009;17:145364. https://doi.org/10.1038/mt.2009.83.

105. Zhao Z, Condomines M, van der Stegen SJC, Perna F, Kloss CC, Gunset G, et al. Structural design of engineered costimulation determines tumor rejection kinetics and persistence of CAR T cells. Cancer Cell. 2015;28:415-28. https://doi.org/10.1016/j. ccell.2015.09.004

106. Guedan S, Chen X, Madar A, Carpenito C, McGettigan SE, Frigault MJ, et al. ICOS-based chimeric antigen receptors program bipolar TH17/TH1 cells. Blood. 2014;124:1070-80. https://doi.org/10.1182/blood-2013-10-535245. 
107. Song D-G, Ye Q, Poussin M, Harms GM, Figini M, Powell DJ. CD27 costimulation augments the survival and antitumor activity of redirected human T cells in vivo. Blood. 2012;119:696-706. https://doi.org/10.1182/blood-2011-03-344275.

108. Guedan S, Madar A, Casado-Medrano V, Shaw C, Wing A, Liu F, et al. Single residue in CD28-costimulated CAR-T cells limits long-term persistence and antitumor durability. J Clin Invest. 2020;130:3087-97. https://doi.org/10.1172/JCI133215.

109. Hirayama AV, Gauthier J, Hay KA, Voutsinas JM, Wu Q, Pender BS, et al. High rate of durable complete remission in follicular lymphoma after CD19 CAR-T cell immunotherapy. Blood. 2019;134:636-40. https://doi.org/10.1182/blood.2019000905.

110. Kagoya Y, Tanaka S, Guo T, Anczurowski M, Wang C-H, Saso $\mathrm{K}$, et al. A novel chimeric antigen receptor containing a JAKSTAT signaling domain mediates superior antitumor effects. Nat Med. 2018;24:352-9. https://doi.org/10.1038/nm.4478.

111. Fraietta JA, Nobles CL, Sammons MA, Lundh S, Carty SA, Reich TJ, et al. Disruption of TET2 promotes the therapeutic efficacy of CD19-targeted T cells. Nature. 2018;558:307-12. https://doi.org/ 10.1038/s41586-018-0178-z.

112. Nishio N, Diaconu I, Liu H, Cerullo V, Caruana I, Hoyos V, et al. Armed oncolytic virus enhances immune functions of chimeric antigen receptor-modified $\mathrm{T}$ cells in solid tumors. Cancer Res. 2014;74:5195-205. https://doi.org/10.1158/0008-5472.CAN-140697.

113. Kloss CC, Condomines M, Cartellieri M, Bachmann M, Sadelain M. Combinatorial antigen recognition with balanced signaling promotes selective tumor eradication by engineered T cells. Nat Biotechnol. 2013;31:71-5. https://doi.org/10.1038/nbt.2459.

114. Wilkie S, van Schalkwyk MCI, Hobbs S, Davies DM, van der Stegen SJC, Pereira ACP, et al. Dual targeting of ErbB2 and MUC1 in breast cancer using chimeric antigen receptors engineered to provide complementary signaling. J Clin Immunol. 2012;32:1059-70. https://doi.org/10.1007/s10875012-9689-9.

115. Fedorov VD, Themeli M, Sadelain M. PD-1- and CTLA-4-based inhibitory chimeric antigen receptors (iCARs) divert off-target immunotherapy responses. Sci Transl Med. 2013;5:215ra172. https://doi.org/10.1126/scitranslmed.3006597.

116. Roybal KT, Rupp LJ, Morsut L, Walker WJ, McNally KA, Park JS, et al. Precision tumor recognition by T cells with combinatorial antigen-sensing circuits. Cell. 2016;164:770-9. https://doi.org/10. 1016/j.cell.2016.01.011.

117. Juillerat A, Marechal A, Filhol JM, Valogne Y, Valton J, Duclert A, et al. An oxygen sensitive self-decision making engineered CAR T-cell. Sci Rep. 2017;7:39833. https://doi.org/10.1038/ srep39833.

118. Han X, Bryson PD, Zhao Y, Cinay GE, Li S, Guo Y, et al. Masked chimeric antigen receptor for tumor-specific activation. Mol Ther. 2017;25:274-84. https://doi.org/10.1016/j.ymthe.2016.10.011.

119. Staflin K, de Zafra Zuch CL, Schutt LK, Clark V, Zhong F, Hristopoulos M, et al. Target arm affinities determine preclinical efficacy and safety of anti-HER2/CD3 bispecific antibody. JCI Insight. 2020. https://doi.org/10.1172/jci.insight.133757.

120. Banaszek A, Bumm TGP, Nowotny B, Geis M, Jacob K, Wölfl $\mathrm{M}$, et al. On-target restoration of a split $\mathrm{T}$ cell-engaging antibody for precision immunotherapy. Nat Commun. 2019, 10:5387. https://doi.org/10.1038/s41467-019-13196-0 Report on a split $\mathrm{BiAb}$ for precise dual antigen targeting.

121. Autio KA, Boni V, Humphrey RW, Naing A. Probody therapeutics: an emerging class of therapies designed to enhance on-target effects with reduced off-tumor toxicity for use in immuno-oncology. Clin Cancer Res. 2020;26:984-9. https://doi.org/10.1158/ 1078-0432.CCR-19-1457.

122. Trang VH, Zhang X, Yumul RC, Zeng W, Stone IJ, Wo SW, et al. A coiled-coil masking domain for selective activation of therapeutic antibodies. Nat Biotechnol. 2019;37:761-5. https:// doi.org/10.1038/s41587-019-0135-X.

123. Feng K-C, Guo Y-L, Liu Y, Dai H-R, Wang Y, Lv H-Y, et al. Cocktail treatment with EGFR-specific and CD133-specific chimeric antigen receptor-modified $\mathrm{T}$ cells in a patient with advanced cholangiocarcinoma. J Hematol Oncol. 2017;10:4. https://doi.org/ 10.1186/s13045-016-0378-7.

124. Ruella M, Barrett DM, Kenderian SS, Shestova O, Hofmann TJ, Perazzelli J, et al. Dual CD19 and CD123 targeting prevents antigen-loss relapses after CD19-directed immunotherapies. J Clin Investig. 2016;126:3814-26. https://doi.org/10.1172/ JCI87366.

125. Hegde M, Corder A, Chow KKH, Mukherjee M, Ashoori A, Kew $\mathrm{Y}$, et al. Combinational targeting offsets antigen escape and enhances effector functions of adoptively transferred $\mathrm{T}$ cells in glioblastoma. Mol Ther. 2013;21:2087-101. https://doi.org/10.1038/ mt.2013.185.

126. Chen KH, Wada M, Pinz KG, Liu H, Shuai X, Chen X, et al. A compound chimeric antigen receptor strategy for targeting multiple myeloma. Leukemia. 2018;32:402-12. https://doi.org/10. 1038/leu.2017.302.

127. Hegde M, Mukherjee M, Grada Z, Pignata A, Landi D, Navai SA, et al. Tandem CAR T cells targeting HER2 and IL13R $\alpha 2$ mitigate tumor antigen escape. J Clin Investig. 2016;126:3036-52. https:// doi.org/10.1172/JCI83416.

128. Jia H, Wang Z, Wang Y, Liu Y, Dai H, Tong C, et al. Haploidentical CD19/CD22 bispecific CAR-T cells induced MRD-negative remission in a patient with relapsed and refractory adult B-ALL after haploidentical hematopoietic stem cell transplantation. J Hematol Oncol. 2019;12:57. https://doi.org/10.1186/ s13045-019-0741-6.

129. Shah NN, Zhu F, Schneider D, Taylor C, Krueger W, Worden A, et al. Results of a phase I study of bispecific anti-CD19, anti-CD20 chimeric antigen receptor (CAR) modified $\mathrm{T}$ cells for relapsed, refractory, non-Hodgkin lymphoma. JCO. 2019;37:2510. https:// doi.org/10.1200/JCO.2019.37.15_suppl.2510.

130. Tong C, Zhang Y, Liu Y, Ji X, Zhang W, Guo Y, et al. Optimized tandem CD19/CD20 CAR-engineered T cells in refractory/ relapsed B-cell lymphoma. Blood. 2020;136:1632-44. https:// doi.org/10.1182/blood.2020005278.

131. Cartellieri M, Feldmann A, Koristka S, Arndt C, Loff S, Ehninger A, et al. Switching CAR T cells on and off: a novel modular platform for retargeting of T cells to AML blasts. Blood Cancer J. 2016;6:e458. https://doi.org/10.1038/bcj.2016.61.

132. Arndt C, Feldmann A, Koristka S, Cartellieri M, Dimmel M, Ehninger A, et al. Simultaneous targeting of prostate stem cell antigen and prostate-specific membrane antigen improves the killing of prostate cancer cells using a novel modular T cellretargeting system. Prostate. 2014;74:1335-46. https://doi.org/ 10.1002 pros. 22850 .

133. Wing A, Fajardo CA, Posey AD, Shaw C, Da T, Young RM, et al. Improving CART-cell therapy of solid tumors with oncolytic virus-driven production of a bispecific T-cell engager. Cancer Immunol Res. 2018;6:605-16. https://doi.org/10.1158/23266066.CIR-17-0314.

134. Di Stasi A, de Angelis B, Rooney CM, Zhang L, Mahendravada A, Foster AE, et al. T lymphocytes coexpressing CCR4 and a chimeric antigen receptor targeting CD30 have improved homing and antitumor activity in a Hodgkin tumor model. Blood. 2009;113:6392-402. https://doi.org/10.1182/blood-2009-03209650.

135. Craddock JA, an Lu Bear A, Pule M, Brenner MK, Rooney CM, Foster AE. Enhanced tumor trafficking of GD2 chimeric antigen receptor $\mathrm{T}$ cells by expression of the chemokine receptor CCR2b. J immunother (Hagerstown, Md : 1997). 2010;33:780-8. https:// doi.org/10.1097/CJI.0b013e3181ee6675. 
136. Kershaw MH, Wang G, Westwood JA, Pachynski RK, Tiffany HL, Marincola FM, et al. Redirecting migration of T cells to chemokine secreted from tumors by genetic modification with CXCR2. Hum Gene Ther. 2002;13:1971-80. https://doi.org/10. 1089/10430340260355374.

137. Wang L-CS, Lo A, Scholler J, Sun J, Majumdar RS, Kapoor V, et al. Targeting fibroblast activation protein in tumor stroma with chimeric antigen receptor $\mathrm{T}$ cells can inhibit tumor growth and augment host immunity without severe toxicity. Cancer Immunol Res. 2014;2:154-66. https://doi.org/10.1158/23266066.CIR-13-0027.

138. Caruana I, Savoldo B, Hoyos V, Weber G, Liu H, Kim ES, et al. Heparanase promotes tumor infiltration and antitumor activity of CAR-redirected T lymphocytes. Nat Med. 2015;21:524-9. https:// doi.org/10.1038/nm.3833.

139. Adachi K, Kano Y, Nagai T, Okuyama N, Sakoda Y, Tamada K. IL-7 and CCL19 expression in CAR-T cells improves immune cell infiltration and CAR-T cell survival in the tumor. Nat Biotechnol. 2018;36:346-51. https://doi.org/10.1038/nbt.4086.

140. Watanabe K, Luo Y, Da T, Guedan S, Ruella M, Scholler J, et al. Pancreatic cancer therapy with combined mesothelin-redirected chimeric antigen receptor $\mathrm{T}$ cells and cytokine-armed oncolytic adenoviruses. JCI Insight. 2018;3. https://doi.org/10.1172/jci. insight.99573.

141. Fajardo CA, Guedan S, Rojas LA, Moreno R, Arias-Badia M, de Sostoa J, et al. Oncolytic adenoviral delivery of an EGFRtargeting T-cell engager improves antitumor efficacy. Cancer Res. 2017;77:2052-63. https://doi.org/10.1158/0008-5472.CAN16-1708.

142. Cao Y, Lu W, Sun R, Jin X, Cheng L, He X, et al. Anti-CD19 chimeric antigen receptor $\mathrm{T}$ cells in combination with nivolumab are safe and effective against relapsed/refractory B-cell nonHodgkin lymphoma. Front Oncol. 2019;9:767. https://doi.org/ 10.3389/fonc. 2019.00767 .

143. Jacobson CA, Locke FL, Miklos DB, Herrera AF, Westin JR, Lee $\mathrm{J}$, et al. End of phase 1 results from Zuma-6: axicabtagene ciloleucel (Axi-Cel) in combination with atezolizumab for the treatment of patients with refractory diffuse large B cell lymphoma. Blood. 2018;132:4192. https://doi.org/10.1182/BLOOD2018-99-111523.

144. Ren J, Liu X, Fang C, Jiang S, June CH, Zhao Y. Multiplex genome editing to generate universal CAR $\mathrm{T}$ cells resistant to PD1 inhibition. Clin Cancer Res. 2017;23:2255-66. https://doi. org/10.1158/1078-0432.CCR-16-1300.

145. Ren J, Zhang X, Liu X, Fang C, Jiang S, June CH, et al. A versatile system for rapid multiplex genome-edited CAR T cell generation. Oncotarget. 2017;8:17002-11. https://doi.org/10.18632/ oncotarget.15218.

146. Beavis PA, Henderson MA, Giuffrida L, Mills JK, Sek K, Cross $\mathrm{RS}$, et al. Targeting the adenosine $2 \mathrm{~A}$ receptor enhances chimeric antigen receptor T cell efficacy. J Clin Investig. 2017;127:929-41. https://doi.org/10.1172/JCI89455.

147. Kloss CC, Lee J, Zhang A, Chen F, Melenhorst JJ, Lacey SF, et al. Dominant-negative TGF- $\beta$ receptor enhances PSMA-targeted human CAR T cell proliferation and augments prostate cancer eradication. Mol Ther. 2018;26:1855-66. https://doi.org/10.1016/j. ymthe.2018.05.003.

148. Cherkassky L, Morello A, Villena-Vargas J, Feng Y, Dimitrov DS, Jones DR, et al. Human CAR T cells with cell-intrinsic PD1 checkpoint blockade resist tumor-mediated inhibition. J Clin Investig. 2016;126:3130-44. https://doi.org/10.1172/JCI83092.
149. Yamamoto TN, Lee P-H, Vodnala SK, Gurusamy D, Kishton RJ, $\mathrm{Yu} \mathrm{Z}$, et al. T cells genetically engineered to overcome death signaling enhance adoptive cancer immunotherapy. J Clin Investig. 2019;129:1551-65. https://doi.org/10.1172/JCI121491.

150. Kobold S, Grassmann S, Chaloupka M, Lampert C, Wenk S, Kraus F, et al. Impact of a new fusion receptor on PD-1mediated immunosuppression in adoptive $\mathrm{T}$ cell therapy. J Natl Cancer Inst. 2015;107. https://doi.org/10.1093/jnci/djv146.

151. Leen AM, Sukumaran S, Watanabe N, Mohammed S, Keirnan J, Yanagisawa R, et al. Reversal of tumor immune inhibition using a chimeric cytokine receptor. Mol Ther. 2014;22:1211-20. https:// doi.org/10.1038/mt.2014.47.

152. Suarez ER, Chang DK, Sun J, Sui J, Freeman GJ, Signoretti S, et al. Chimeric antigen receptor T cells secreting anti-PD-L1 antibodies more effectively regress renal cell carcinoma in a humanized mouse model. Oncotarget. 2016;7:34341-55. https://doi.org/ 10.18632/oncotarget.9114.

153. Li S, Siriwon N, Zhang X, Yang S, Jin T, He F, et al. Enhanced cancer immunotherapy by chimeric antigen receptor-modified $\mathrm{T}$ cells engineered to secrete checkpoint inhibitors. Clin Cancer Res. 2017;23:6982-92. https://doi.org/10.1158/1078-0432.CCR-170867.

154. Koneru M, Purdon TJ, Spriggs D, Koneru S, Brentjens RJ. IL-12 secreting tumor-targeted chimeric antigen receptor T cells eradicate ovarian tumors in vivo. Oncoimmunology. 2015;4:e994446. https://doi.org/10.4161/2162402X.2014.994446.

155. Hoyos V, Savoldo B, Quintarelli C, Mahendravada A, Zhang M, Vera J, et al. Engineering CD19-specific T lymphocytes with interleukin-15 and a suicide gene to enhance their anti-lymphoma/leukemia effects and safety. Leukemia. 2010;24:1160-70. https://doi.org/10.1038/leu.2010.75.

156. Hu B, Ren J, Luo Y, Keith B, Young RM, Scholler J, et al. Augmentation of antitumor immunity by human and mouse CAR T cells secreting IL-18. Cell Rep. 2017;20:3025-33. https://doi.org/10.1016/j.celrep.2017.09.002.

157. Tanoue K, Rosewell Shaw A, Watanabe N, Porter C, Rana B, Gottschalk S, et al. Armed oncolytic adenovirus-expressing PDL1 mini-body enhances antitumor effects of chimeric antigen receptor T cells in solid tumors. Cancer Res. 2017;77:2040-51. https://doi.org/10.1158/0008-5472.CAN-16-1577.

158. ClinicalTrials.gov. NCT02879695. https://clinicaltrials.gov/ct2/ show/NCT02879695?term=NCT02879695\&rank=1. Accessed 9 Oct 2020.

159. Krupka C, Kufer P, Kischel R, Zugmaier G, Lichtenegger FS, Köhnke T, et al. Blockade of the PD-1/PD-L1 axis augments lysis of AML cells by the CD33/CD3 BiTE antibody construct AMG 330: reversing a T-cell-induced immune escape mechanism. Leukemia. 2016;30:484-91. https://doi.org/10.1038/leu.2015. 214.

160. Claus C, Ferrara C, Xu W, Sam J, Lang S, Uhlenbrock F, et al. Tumor-targeted 4-1BB agonists for combination with $\mathrm{T}$ cell bispecific antibodies as off-the-shelf therapy. Sci Transl Med. 2019. https://doi.org/10.1126/scitranslmed.aav5989 Combination of CD3-engaging BiAb with bispecific 4-1BB agonists.

Publisher's Note Springer Nature remains neutral with regard to jurisdictional claims in published maps and institutional affiliations. 